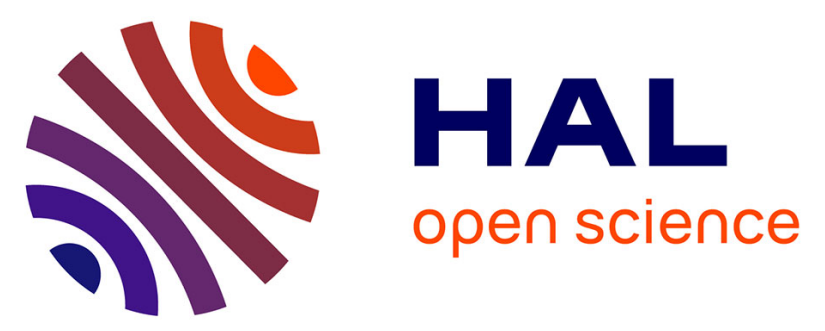

\title{
Fluvial landscape evolution controlled by the sediment deposition coefficient: Estimation from experimental and natural landscapes
}

Laure Guerit, Xiao-Ping Yuan, Sebastien Carretier, Stephane Bonnet, Sébastien Rohais, Jean Braun, Delphine Rouby

\section{To cite this version:}

Laure Guerit, Xiao-Ping Yuan, Sebastien Carretier, Stephane Bonnet, Sébastien Rohais, et al.. Fluvial landscape evolution controlled by the sediment deposition coefficient: Estimation from experimental and natural landscapes. Geology, 2019, 47 (9), pp.853-856. 10.1130/G46356.1 . hal-02397925

\section{HAL Id: hal-02397925 \\ https://hal-ifp.archives-ouvertes.fr/hal-02397925}

Submitted on 16 Nov 2020

HAL is a multi-disciplinary open access archive for the deposit and dissemination of scientific research documents, whether they are published or not. The documents may come from teaching and research institutions in France or abroad, or from public or private research centers.
L'archive ouverte pluridisciplinaire HAL, est destinée au dépôt et à la diffusion de documents scientifiques de niveau recherche, publiés ou non, émanant des établissements d'enseignement et de recherche français ou étrangers, des laboratoires publics ou privés. 


\title{
Fluvial landscape evolution controlled by the sediment
} deposition coefficient: estimation from experimental and natural landscapes

\author{
Laure Guerit', Xiao-Ping Yuan², Sébastien Carretier¹, Stéphane Bonnet'1, Sébastien \\ Rohais $^{3}$, Jean Braun², Delphine Rouby ${ }^{1}$
}

${ }^{1}$ Géosciences Environnement Toulouse, UMR5563 CNRS-IRD-Université de Toulouse, France ${ }^{2}$ Helmholtz Centre Potsdam, German Research Centre for Geosciences, Potsdam, Germany 3IFPEN, Direction Géosciences, 1 et 4 Avenue de Bois-Préau, 92852 Rueil-Malmaison Cedex, France

\begin{abstract}
The evolution of a fluvial landscape is a balance between tectonic uplift, fluvial erosion and sediment deposition. The erosion term can be expressed according to the stream power model, stating that fluvial incision is proportional to powers of river slope and discharge.

The deposition term can be expressed as proportional to the sediment flux divided by a transport length. This length can be defined as the water flux times a scaling factor $\zeta$. This factor exerts a major control on the river dynamics, on the spacing between sedimentary bedforms, or on the overall landscape erosional behavior. Yet, this factor is difficult to measure either in the lab or on the field. Here, we propose a new formulation for the deposition term based a dimensionless coefficient $G$ which can be estimated at the scale of a landscape, from the slopes of rivers at the transition between a catchment and its fan. We
\end{abstract}


estimate this deposition coefficient from 29 experimental catchment-alluvial fan systems and 68 natural examples. Based on our data set, we support the idea of Davy and Lague (2009) that the dimensionless deposition coefficient $G$ is a relevant parameter to characterize the erosional and transport mode of a fluvial landscape, which can be field-calibrated, with a continuum from detachment-limited $(G=0)$ to transport-limited behavior ( $G>0.4$ from the studied examples).

\section{INTRODUCTION}

Continental landscapes constantly evolve in response to tectonics and climate via erosion, sediment transport and deposition. Based on a simple mass balance, the evolution of a topography through time can be expressed as:

$$
\frac{d h}{d t}=U-E+D,(1)
$$

where $h$ is the topographic elevation (m), $t$ is the time (yr), $U$ is the uplift rate (m/yr), $E$ is the erosion rate $(\mathrm{m} / \mathrm{yr})$, and $D$ is the deposition rate $(\mathrm{m} / \mathrm{yr})$.

According to the stream power model (Howard and Kerby, 1983; Howard et al., 1994; Whipple and Tucker, 1999; Lague, 2014), the erosion rate at steady state along river channels can be expressed as:

$$
E=K_{f}(P A)^{m} S^{n},(2)
$$

where $K_{f}$ is the erodibility ( $\left.\mathrm{m}^{1-3 \mathrm{~m}} \mathrm{yr}^{\mathrm{m}-1}\right), P$ is the effective precipitation rate (m/yr), $A$ is the drainage area $\left(\mathrm{m}^{2}\right), S$ is the slope, and $m$ and $n$ are two coefficients.

Kooi and Beaumont (1994) suggested that the deposition term $D$ is equal to the sediment flux $q_{S}\left(\mathrm{~m}^{2} / \mathrm{yr}\right)$ divided by a transport length $L(\mathrm{~m})$. The transport length can be seen 
as the distance a grain can travel within the flow before it is deposited on the river bed, and it exerts a strong control on river morpho-dynamics (Davy and Lague, 2009; Bradley et al., 2012; Ganti et al., 2014; Kaspark et al., 2015; An et al., 2018).

Davy and Lague (2009) improved this formulation by relating $L$ to the sediment concentration in the water column and to the net settling velocity of the grains which depends on the flow and particles characteristics. The transport length has been implemented as proportional to the water discharge $q_{w}\left(\mathrm{~m}^{2} / \mathrm{yr}\right)$ in several models to give:

$$
D=\frac{q_{s}}{L}=\frac{q_{s}}{q_{w} \zeta},(3)
$$

where $\zeta$ is a scaling factor $(\mathrm{yr} / \mathrm{m})$. Equations (1-3) are used to model small range and foreland up to mega-fans (Carretier et al., 2016; Mouchené et al., 2017; Shobe et al, 2017; Langston and Tucker, 2018).

For a given water discharge, when $\zeta$ is low, it is the ability of river to transport sediments that controls the rate of landscape evolution (transport-limited system, TL), whereas it is controlled by the ability of rivers to erode and provide sediments to the system when $\zeta$ is high (detachment-limited system, DL) (Davy and Lague, 2009). These two endmember modes lead to similar steady-state landscapes but their transient behavior can be quite distinct (Tucker and Whipple, 2002; Davy and Lague, 2009). For example, the response of a landscape to a climatic change will be faster for a TL system than for a DL one (Armitage et al., 2018). Accurate estimation of $\zeta$ is thus required for landscape evolution models and to understand the response of continental landscapes to perturbations in tectonics or climate. However, the scaling factor $\zeta$ is defined from physical parameters related to the particles in transport and to characteristics of the flow that are difficult to estimate in natural systems. 


\section{APPROACH}

We develop here a method allowing a simple estimation of the deposition coefficient from the landscape morphology. Considering local equilibrium, the sediment flux $q_{s}$ can be expressed as the integrated upstream net erosion rate. Assuming uniform precipitation $P$ over the upstream catchment of area $A$, the water flux $q_{w}$ is equal to the product of $A$ and $P$. We thus rewrite the deposition term as:

$$
D=\frac{1}{A P \zeta} \int_{A}\left(U-\frac{\partial h}{\partial t}\right) d A=\frac{G}{A} \int_{A}\left(U-\frac{\partial h}{\partial t}\right) d A,(4)
$$

where $G=1 /(P \zeta)$ is a dimensionless coefficient which controls the local deposition rate.

This coefficient has a strong impact on the drainage density and landscape morphology (Carretier et al., 2018; their $N_{\text {depo }}$ ), and Davy and Lague (2009) proposed that $G$ (their equation 16) determines the DL- or TL-like nature of the topographic evolution $(G>1$ or $G<1$ for $n=1$ ). Equation (1) thus reads (Yuan et al., 2019):

$$
\frac{\partial h}{\partial t}=U-K_{f}(P A)^{m} S^{n}+\frac{G}{A} \int_{A}\left(U-\frac{\partial h}{\partial t}\right) d A .(5)
$$

Consider an uplifting area surrounded by a sedimentary basin where alluvial fans can develop. We define $U$ as the vertical displacement relative to the basin's basement (i.e., the sedimentary basin is fixed). At steady state, the rate of topographic change $\partial h / \partial t$ is equal to zero. Accordingly, in the uplifting area, Equation (5) reduces to:

$$
(1+G) U=K_{f}(A P)^{m} S_{R}^{n},(6)
$$

and along the fans in the sedimentary basins, where there is no uplift, it reduces to: 


$$
G U=K_{f}(A P)^{m} S_{F}^{n},(7)
$$

where $S_{R}$ and $S_{F}$ refer to the river slopes in the range and along the fan, respectively. At the coupling point of these two domains, combining Equations (6) and (7) leads to:

$$
G=\frac{S_{F}^{n}}{S_{R}^{n}-S_{F}^{n}}
$$

We can thus estimate the deposition coefficient $G$ from the slopes of the rivers near the coupling point between a catchment and its fan. This equation is derived at the coupling point of catchment-fan system and therefore, only local steady-state river profile is required to estimate $G$ from equation (8). Diffusive processes along hillslopes could be added to Equation (5). However, we focus here on river profiles at the catchment outlets and we thus neglect this process for the sake of simplicity.

In the following, we apply this methodology to experimental and natural catchmentfan system to estimate $G$ and the corresponding scaling factors $\zeta$. We then discuss implications in terms of sediment transport and catchment dynamics.

\section{$G$ FROM EXPERIMENTAL LANDSCAPES}

We selected two sets of laboratory experiments where an uplifted area submitted to rainfall erosion is coupled to a depositional zone (Babault et al., 2005; Rohais, 2007; Rohais et al., 2012). Details about the experiments are presented in the GSA Data Repository Text ${ }^{1}$ and are summarized here.

Rohais (2007) and Rohais et al. (2012) used a rectangular erosion box with a single outlet coupled to a depositional plateau to simulate an uplifting catchment and its alluvial fan (Fig. 1A, Fig. DR1). The catchment only is submitted to rainfall. Babault et al. (2005) used a 
rectangular box surrounded by a depositional plateau to simulate an uplifted range with multiple outlets and associated fans (Fig. 1B, Fig. DR2). The whole landscape is submitted to rainfall. In the 14 experiments analyzed, the erosion box is filled with similar silica powder, uplift is uniform and applied at a constant rate in the catchment areas, and erosion is induced by rainfall from sprinklers located above. Optical stereo data were acquired to build DEMs of the experiments (horizontal resolution: $0.5-1 \mathrm{~mm} /$ pixel, vertical resolution $<0.5 \mathrm{~mm} /$ pixel). Based on a large dataset of experiments (Moussirou and Bonnet, 2018), Moussirou (2018) shows that the time to reach steady-state non-linearly depends on $U$. According to the stream power model, this implies an exponant $n>1$ in Equation (2), with a value of $n=1.7 \pm 0.2$ for the material used here. This is in agreement with estimations from similar experiments (Viaplana-Muzas et al., 2018).

With each experiment, we used landscapes at steady-state (constant mean elevation through time in the uplifted zone) and determined the drainage network with Topotoolbox Matlab subroutines (Schwanghart and Khun, 2010). We extracted the river profiles along a few centimeters on both sides of the river outlets and calculated the river slope in the range $S_{R}$ and along the fan $S_{F}$ by linear regressions (Figs. 1C-D, DR1, DR2, Table DR1). In total, 29 catchment-fan systems were analyzed. The experiments are performed with the same lithology and erosion processes. We therefore expect $G$ to be similar in all the experiments. Estimates of $G$ are consistent whatever the experimental designs or the applied forcings: values range between 0.4 and 1.9 (Figs. 2 and DR3, Table DR1). A whisker plot suggests that $G=1.9$ is an anomaly (Fig. 2B). Excluding this point, we observe that the experiments are characterized by $G \in[0.4-1.2]$ with a median value of 0.7 (Fig. 2B). 


\section{$G$ FROM NATURAL LANDSCAPES}

We applied the same approach to natural landscapes and selected 68 systems of coupled catchment-fan systems worldwide based on the visual identification of alluvial bodies in sedimentary basins. We excluded fans that are cut or deformed by obvious tectonic features to avoid out-of-equilibrium systems. Two well-individualized catchment-fan systems and six systems of adjacent fans were selected as an equivalent to the two sets of experiments. We also analyzed fan deltas to document extensional settings. The data set cover a variety of tectonic and climatic settings and is composed of small (debris-flow dominated) to very large (mega-fans) systems (Table DR2, Figs. DR4-13).

For each site, we mapped the sedimentary system on GoogleEarth images (Figs. 3A and DR4-13) and we used Topotoolbox Matlab subroutines (Schwanghart and Khun, 2010) to extract the main river path close to the apex using ASTER DEMs (horizontal resolution: 30 m, vertical resolution: $10 \mathrm{~m}$, Fig. 3B). A river profile at steady state can be converted into a straight line by a slope transformation $(\chi-h$ plots introduced by Perron and Royden, 2012) . Such plot are less influenced by noise associated to DEM resolution than simple slope plots. We therefore used $\chi-h$ plots to identify the longest linear segment of the river upstream of the apex (typically a few $\mathrm{km}$ ) and we assumed that it is at steady state. We then measured the slopes by linear fit along this segment and along the fan, a few $\mathrm{km}$ downstream of the apex (Figs. 3C, DR4-13, Table DR2). Several studies suggest $n>1$ for natural landscapes and a median of 2 emerges from worldwide database (DiBiase and Whipple, 2011; Whittaker and Boulton, 2012; Lague, 2014; Harel et al., 2016). In the following, we thus use $n=2 \pm 0.5$ for all sites.

Estimates of $G$ are more scattered than the experimental ones. Three systems ( $5 \%$ of the data set) show a slope continuity from the catchment to the fan, implying $G \rightarrow \infty$. 
Excluding these systems, $G$ ranges from $\sim 0$ to 3.1 (Fig. 4 and DR3, Table DR2). A more linear relationship between slope and erosion would lead to higher values of $G$ but in the same order of magnitude (Fig. DR14).

\section{DISCUSSION}

To calibrate $G$, we assume that $K_{f}$ and $P$ are uniform in space at the scale of the catchment-fan system. These assumptions are correct in the experiments made with a unique material evolving under uniform rainfall. For these systems, we suggest that the variability observed around the median value ( $\pm 50 \%$, Fig. 2$)$ is related to local variations in material properties (i.e. particle size) and in precipitation rate, which can not be perfectly controlled in such setups. This could be considered as an intrinsic variability associated to $G$.

The variability observed for natural systems is higher than the experimental one (Fig. 4). We propose that it partly comes from violation of our assumptions (e.g., steady state, uniform $K_{f}$ and $P$ ). In natural settings, $K_{f}$ and $P$ may vary at the scale of the catchment-fan system. However, most channels are covered by sediments (e.g., Turowski et al, 2008), and within-catchment variations should be averaged at the river outlets where we estimate $G$. At the scale of a catchment-fan system, it is thus reasonable to assume locally uniform $K_{f}$ and that $P$ is the catchment-averaged precipitation rate. Within a given study site, different lithologies between catchments could induce differences in $K_{f}$ and in grain sizes which potentially influence sediment transport and deposition.

We also assume landscapes at steady-state, which is again correct for the experiments.

For the natural systems, the $\chi-h$ plots of the river profiles close to the apexes suggest that these segments are in equilibrium. However, alluvial fans are typically sensitive to temporal 
variations at the scale of $10^{2-10^{5}}$ yrs (Hinderer, 2012) and systems responding to such variations (out-of-equilibrium systems, $\partial h / \partial t \neq 0$ ) could explain part of the variability observed on $G$.

Beyond those uncertainties, we observe a correlation between $G$ and the slope of the river in the range, and between $G$ and the drainage area (Fig. DR15A-B). Steep rivers and small catchments tend to be associated with low values of $G$ and vice versa. This may reveal a difference in fluvial dynamics. In fact, based on previous studies, we propose that experimental landscapes tend toward a TL mode. Using a similar laboratory setting, Lague et al. (2003) showed that their experiments are best reproduced by a TL model. Based on similar experiments, Turowski et al. (2006) concluded that a DL model is unable to reproduce their observations. We thus argue that the coefficient $G$ characterizes the erosional and transport behaviors of a landscape for a large range of spatial and temporal scales. Based on our estimates, we propose that $G>0.4$ indicates a system tending toward a TL mode.

About $1 / 3$ of the natural systems studied here show a $G$ lower than 0.4 (Fig. 4). Those systems should thus be close to a pure DL mode, well-described by the stream power model. The remaining $2 / 3$ are characterized by a large range of $G$ (from 0.4 to $\infty$ ) which should indicate systems transitioning from DL to TL mode, up to pure TL mode $(G \rightarrow \infty)$. Natural landscapes thus seem to describe a continuum between the two modes with a preference for TL mode (as suggested by Davy and Lague, 2009), supporting the use of landscape models coupling erosion and deposition in a single equation.

Finally, we can estimate the scaling factor $\zeta$ from $G$ (Equation (4)). In the experiments, we observe similar estimated $\zeta$ with a median of $1.7 \times 10^{-3} \mathrm{yr} / \mathrm{m}$ (Fig. DR16A). For the natural systems, the estimated $\zeta$ show a large dispersion with a median of $17 \mathrm{yr} / \mathrm{m}$ 
(Fig. DR16B). Davy and Lague (2009) defined the scaling factor as $\zeta=1 /\left(d^{*} v_{s}\right)$, where $d^{*}$ is the ratio of the sediment concentration near the bed and within the flow, and $v_{s}$ is the effective settling velocity of the particles. The estimated values of $\zeta$ for the natural systems lead to unrealistic low settling velocities of maximum $10^{-8} \mathrm{~m} / \mathrm{s}$. When measured from natural topography, the apparent scaling factor thus appears to be overestimated. This could be related to an underestimation of the morphogenic $P$ (as we only have access to the present-day, average $P$ ) or to the intermittency of natural rainfall that induces intermittent transport. Such transport can lead to an overestimation of $\zeta$ (GSA Data Repository Text).

\section{CONCLUSIONS}

We propose a simple formulation for fluvial landscape evolution taking into account sediment deposition. The deposition term is characterized by a dimensionless coefficient $G$. This coefficient is related to a scaling factor $\zeta$ that controls river bedforms and fluvial dynamics from a detachment-limited (DL) mode to a transport-limited (TL) mode. Although this factor is key to describe fluvial dynamics and landscape evolution, $\zeta$ is difficult to measure on natural landscapes. On the contrary, $G$ is easy to estimate from topographic data. We measured this coefficient on experimental and natural landscapes across a large variety of tectonic and climatic settings. Experimental values are within [0.4-1.2] while field values range from 0 to $\infty$. Supporting previous works, we propose that $G$ characterizes the erosional and transport behaviors of a landscape and based on our estimates, $G>0.4$ should indicate a system in transition from DL to TL mode. Accordingly, $2 / 3$ of the studied natural examples tend toward a TL dynamics. 


\section{ACKNOWLEDGMENTS}

This work is part of the COLORS project funded by Total. We thank John Armitage, Katy Barnhart, Jeffrey Kwang, an anonymous reviewer and the journal editor for their comments that greatly improved the manuscript.

\section{REFERENCES CITED}

An, C., Moodie, A., Ma, H., Fu, X., Zhang, Y., Naito, K., and Parker, G., 2018, Morphodynamic model of the lower Yellow River: flux or entrainment form for sediment mass conservation?, Earth Surface Dynamics, v. 6, p. 989-1010.

Armitage, J., Whittaker, A., Zakari, M., and Campforts, B., 2018, Numerical modelling of landscape and sediment flux response to precipitation rate change: Earth Surface Dynamics, v. 6, no. 1, p. 77-99.

Babault, J., Bonnet, S., Crave, A., and Van Den Driessche, J., 2005, Influence of piedmont sedimentation on erosion dynamics of an uplifting landscape: an experimental approach Geology, v. 33, no. 4, p. 301-304.

Bradley, D., and Tucker, G., 2012, Measuring gravel transport and dispersion in a mountain river using passive radio tracers: Earth Surface Processes and Landforms, v. 37, no. 10, p. $1034-1045$.

Carretier, S., Martinod, P., Reich, M., and Godderis, Y., 2016, Modelling sediment clasts transport during landscape evolution: Earth Surface Dynamics, v. 4, no. 1, p. 237-251.

Carretier, S., Goddéris, Y., Martinez, J., Reich, M., and Martinod, P., 2018, Colluvial deposits as a possible weathering reservoir in uplifting mountains: Earth Surface Dynamics, v. 6, no. 1, p. $217-237$. 
Davy, P., and Lague, D., 2009, Fluvial erosion/transport equation of landscape evolution models revisited: Journal of Geophysical Research, v. 114, F03007.

DiBiase, R., and Whipple, K., 2011, The influence of erosion thresholds and runoff variability on the relationships among topography, climate, and erosion rate: Journal of Geophysical Research, v. 116, F04036.

Ganti, V., Lamb, M., and McElroy, B., 2014, Quantitative bounds on morphodynamics and implications for reading the sedimentary record: Nature communications, v. 5, p. 3298.

Harel, M.-A., Mudd, S.M., and Attal, M., 2016, Global analysis of the stream power law parameters based on worldwide 10Be denudation rates: Geomorphology, v. 268, p. 184196.

Hinderer, M., 2012, From gullies to mountain belts: A review of sediment budgets at various scales: Sedimentary Geology, v. 280, p. 21-59.

Howard, A., and Kerby, G., 1983, Channel changes in badlands: Geological Society of America Bulletin, v. 94, no. 6, p. 739-752.

Howard, A., Dietrich, W., and Seidl, M., 1994, Modeling fluvial erosion on regional to continental scales: Journal of Geophysical Research, v. 99, no. B7, p. 13971-13986.

Kasprak, A., Wheaton, J., Ashmore, P., Hensleigh, J., and Peirce, S., 2015, The relationship between particle travel distance and channel morphology: Results from physical models of braided rivers: Journal of Geophysical Research, v. 120, no. 1, p. 55-74.

Kooi, H., and Beaumont, C., 1994, Escarpment evolution on high-elevation rifted margins: Insights derived from a surface processes model that combines diffusion, advection, and reaction: Journal of Geophysical Research, v. 99, no. B6, p. 12191-12209.

Lague, D., 2014, The stream power river incision model: evidence, theory and beyond: Earth Surface Processes and Landforms, v. 39, no. 1, p. 38-61. 
Lague, D., Crave, A., Davy, P., 2003, Laboratory experiments simulating the geomorphic response to tectonic uplift: Journal of Geophysical Research, v. 108, no. B1, p. ETG 3-1ETG 3-20.

Langston, A., and Tucker, G., 2018, Developing and exploring a theory for the lateral erosion of bedrock channels for use in landscape evolution models: Earth Surface Dynamics, v. 6, no. 1, p. $1-27$.

Mouchené, M., van der Beek, P., Carretier, S., and Mouthereau, F., 2017, Autogenic versus allogenic controls on the evolution of a coupled fluvial megafan-mountainous catchment system: numerical modelling and comparison with the Lannemezan megafan system (northern Pyrenees, France): Earth Surface Dynamics, v. 5, no. 1, p. 125-143.

Moussirou, B., 2018, Modélisation expérimentale de la dynamique long terme des reliefs en réponse aux forçages climatiques et tectoniques [Ph.D. thesis]: Université Toulouse 3 Paul Sabatier, 283 p.

Moussirou, B., and Bonnet, S., 2018, Modulation of the erosion rate of an uplifting landscape by long-term climate change: An experimental investigation: Geomorphology, v. 303, p. $456-466$.

Perron, T., and Royden, L., 2012, An integral approach to bedrock river profile analysis: Earth Surface Processes and Landforms, v. 38, p. 570-576.

Rohais, S., 2007, Architecture stratigraphique et flux sédimentaires sur la marge sud du golfe de Corinthe (Grèce) : Analyse de terrain, modélisations expérimentales et numériques [Ph.D. thesis]: Université de Rennes 1, 386 p.

Rohais, S., Bonnet, S., and Echard, R., 2012, Sedimentary record of tectonic and climatic erosional perturbations in an experimental coupled catchment-fan system: Basin Research, v. 24, no. 2, p. 198-212. 
Schwanghart, W., and Kuhn, N., 2010, TopoToolbox: A set of Matlab functions for topographic analysis: Environmental Modelling and Software, v. 25, no. 6, p. 770-781.

Shobe, C., Tucker, G., and Barnhart, K., 2017, The SPACE 1.0 model: a Landlab component for 2-D calculation of sediment transport, bedrock erosion, and landscape evolution: Géoscientific Model Development, v. 10, p. 4577-4604.

Tucker, G., and Whipple, K., 2002, Topographic outcomes predicted by stream erosion models: Sensitivity analysis and intermodel comparison: Journal of Geophysical Research, v. 107, no. B9.

Turowski, J., Lague, D., Crave, A., and Hovius, N., 2006, Experimental channel response to tectonic uplift: Journal of Geophysical Research, v. 111, no. F3.

Turowski, J., Hovius, N., Wilson, A., and Hong, M.-J., 2008, Hydraulic geometry, river sediment and the definition of bedrock channels: Geomorphology, v. 99, p. 26-38.

Viaplana-Muzas, M., Babault, J., Dominguez, S., Van Den Driessche, J., and Legrand, X., 2018, Modeling of drainage dynamics influence on sediment routing system in a foldand-thrust belt, Basin Research, v. 31, no. 2, p. 290-310.

Whipple, K. and Tucker, G., 1999, Dynamics of the stream-power river incision model: Implications for height limits of mountain ranges, landscape response timescales, and research needs: Journal of Geophysical Research, v. 104, no. B8, p. 17661-17674.

Whittaker, A., and Boulton, S., 2012, Tectonic and climatic controls on knickpoint retreat rates and landscape response times: Journal of Geophysical Research, v. 117, F02024. Yuan, X.P., Bruan, J., Guerit, L., Rouby, D., and Cordonnier, G., 2019, A new efficient method to solve the stream power law model taking into account sediment deposition: Journal of Geophysical Research, 10.1029/2018JF004867. 


\section{FIGURE CAPTIONS}

Figure 1. Estimation of the average slopes in the mountain range $S_{R}$ and along the fan $S_{F}$ from experimental landscapes. Catchments and fans from A) Babault et al. (2005)'s and B) Rohais (2007)'s experiments, and C) and D) longitudinal profile of the main channel near the fan apex. The range and fan slopes are estimated by a linear fit along the profiles in the catchment and along the fan, respectively.

Figure 2. A) Estimations of the deposition coefficient $G$ from the 14 experiments (gray dot s: Rohais, 2007; Rohais et al., 2012; black dots: Babault et al., 2005). Errorbars account for the maximum and minimum $G$ values considering uncertainties on $n$. B) Whiskerplot for $G$ : the median value is indicated by the red line, the red cross indicates an outlier. Excluding this point, $50 \%$ of the sample is within the box and $100 \%$ is within the black lines.

Figure 3. Extraction of the average river slope in the range $S_{R}$ and in the fan $S_{F}$ for natural systems, example of the Illgraben system (Switzerland). A) Localization of the alluvial fan, its apex and of the main river channel on GoogleEarth image. B) Extraction of the river long profile from ASTER DEM. C) Linear fit of the river slope upstream and downstream of the fan apex to estimate $S_{R}$ and $S_{F}$. See figures DR4-13 for other sites.

Figure 4. Estimations of the deposition coefficient $G$ from several natural systems (Oka=Okavango (Botswana), Ill=Illgraben (Switzerland), DV=Death Valley (US), A1, 
A2=Andes (Argentina), TS1, TS2=Tian Shan (Kazakhstan and China), P=Pindus (Greece), $\mathrm{C}=$ Corinth (Greece), $\mathrm{S}=\mathrm{Suez}(\mathrm{Egypt})$ ). Three estimates tending toward $\infty$ are not represented here for visual purpose. Errorbars account for the maximum and minimum $G$ values considering uncertainties on $n$. The gray band indicates the values estimated from the experiments $(G \in[0.4-1.2])$, suggested to indicate a system in transport-limited.

${ }^{1}$ GSA Data Repository item 201Xxxx, with supplementary method, tables and figures, is available online at www.geosociety.org/pubs/ft20XX.htm, or on request from editing@geosociety.org or Documents Secretary, GSA, P.O. Box 9140, Boulder, CO 80301, USA. 